\title{
Specify Identified Mutation
}

National Cancer Institute

\section{Source}

National Cancer Institute. Specify Identified Mutation. NCI Thesaurus. Code C158845.

A request to enter the specific mutation that was identified in the study. 